Prepared for the U.S. Department of Energy under Contract DE-AC05-76RL01830

\title{
Evaluation of In Situ Grouting as a Potential Remediation Method for the Hanford Central Plateau Deep Vadose Zone
}

\author{
MJ Truex \\ EM Pierce \\ MJ Nimmons \\ SV Mattigod
}

January 2011

Pacific Northwest

NATIONAL LABORATORY

Proudly Operated by Battelle Since 1965 


\title{
DISCLAIMER
}

This report was prepared as an account of work sponsored by an agency of the United States Government. Neither the United States Government nor any agency thereof, nor Battelle Memorial Institute, nor any of their employees, makes any warranty, express or implied, or assumes any legal liability or responsibility for the accuracy, completeness, or usefulness of any information, apparatus, product, or process disclosed, or represents that its use would not infringe privately owned rights. Reference herein to any specific commercial product, process, or service by trade name, trademark, manufacturer, or otherwise does not necessarily constitute or imply its endorsement, recommendation, or favoring by the United States Government or any agency thereof, or Battelle Memorial Institute. The views and opinions of authors expressed herein do not necessarily state or reflect those of the United States Government or any agency thereof.

\author{
PACIFIC NORTHWEST NATIONAL LABORATORY \\ operated by \\ BATTELLE \\ for the \\ UNITED STATES DEPARTMENT OF ENERGY \\ under Contract DE-AC05-76RL01830 \\ Printed in the United States of America \\ Available to DOE and DOE contractors from the \\ Office of Scientific and Technical Information, \\ P.O. Box 62, Oak Ridge, TN 37831-0062; \\ ph: (865) 576-8401 \\ fax: $(865) 576-5728$ \\ email: reports@adonis.osti.gov

\begin{abstract}
Available to the public from the National Technical Information Service, U.S. Department of Commerce, 5285 Port Royal Rd., Springfield, VA 22161 ph: (800) 553-6847 fax: $(703) 605-6900$ email: orders@ntis.fedworld.gov online ordering: http://www.ntis.gov/ordering.htm
\end{abstract}

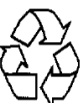

This document was printed on recycled paper. 


\title{
Evaluation of In Situ Grouting as a Potential Remediation Method for the Hanford Central Plateau Deep Vadose Zone
}

\author{
MJ Truex \\ EM Pierce ${ }^{1}$ \\ MJ Nimmons \\ SV Mattigod
}

January 2011

Prepared for

the U.S. Department of Energy

under Contract DE-AC05-76RL01830

Pacific Northwest National Laboratory

Richland, Washington 99352

\footnotetext{
${ }^{1}$ Oak Ridge National Laboratory, Tennessee.
} 



\section{Executive Summary}

The Deep Vadose Zone Treatability Test Plan for the Hanford Central Plateau (DOE/RL 2008) identifies in situ grouting as a potential remediation technology for the deep vadose zone and includes a planned effort to evaluate in situ grouting to provide information for future feasibility studies. This report represents the first step in this evaluation effort. Multiple types of grout/binding materials and emplacement techniques have been developed and demonstrated. Jet grouting and permeation grouting are the two general categories potentially applicable for subsurface contaminant applications at the Hanford Site. Jet grouting uses high-energy emplacement of cement or chemical grout materials whereby the sediment is displaced and mixed with the grouting material. Jet grouting is a well-established technology for shallow applications and use for the deep vadose zone can be extrapolated from the shallow zone practices. Because jet grouting information is readily available for use in feasibility studies, this evaluation focuses on permeation grouting for application in the deep contaminated vadose zone. Permeation grouting is the injection of a liquid grout that fills the natural porosity and then gels to form a solid void-filling material. While permeation grouting is a relatively mature technology for many applications, there are uncertainties with use of grout for in situ contaminant stabilization.

Two general types of permeation grouting approaches may be applicable to address deep vadose zone contamination in the Hanford Central Plateau. Grout could be injected to form a low-permeability layer above, and potentially surrounding the contamination that deflects infiltrating moisture and thereby slows downward contaminant migration. The grouted layers would have grout filling the pore space between sediment grains, but voids may be present because of incomplete filling during injection, and where grout injections have not coalesced to form a contiguous barrier. For some grouts, shrinkage over time may also cause some void formation. While grout would not be an impermeable barrier, slowing the contaminant flux may be sufficient to meet remediation goals similarly to how other in situ remedies such as desiccation or reactive gases act to limit contaminant flux.

In some cases, grout could be injected directly into the contaminated sediment zones to encapsulate contaminants and limit contact with infiltrating water (e.g., volumetric encapsulation). In the vadose zone, grout applied to encapsulate contaminants directly is not expected to create a monolith like a grouted waste form that is prepared above ground. The grout will fill pore space between the sediment grains, although some void space in the grouted region may occur. Thus, volumetric encapsulation does not create an impermeable monolith, but would be expected to reduce the flux of water through the contaminated zone.

Two chemical grouts are recommended for consideration in the Hanford Site vadose zone: acrylamide and silicate grouts. Both materials can be formulated for low viscosities and controlled gelling times. The two chemical grout candidates both have potential limitations because of voids from nonuniform injection. Void formation over time because of shrinkage may also occur under some conditions. The dominant contaminant release mechanism is expected to be from contaminants that remain associated with the pore water/sediment surfaces and are transported with water infiltration through voids in the grout or where grout injections have not coalesced to form a contiguous barrier.

Grout penetration distance is a primary cost factor and potential physical limitation for permeation grout application in the Hanford Central Plateau deep vadose zone. An estimate of grout penetration can be determined using the analytical approach described in this report and respective information about the 
grout gelling time. In most cases, the grout penetration distance will be small relative to the lateral size of the target treatment zone for Hanford Site applications. Additionally, grout penetration is a strong function of the subsurface properties. General limits for use of permeation grouts are provided in the technical literature and are based on sediment permeability and particle size. Groutability of sediments becomes difficult at permeabilities less than approximately $1 \times 10^{-12} \mathrm{~m}^{2}$ (a hydraulic conductivity of about $1 \times 10^{-3} \mathrm{~cm} / \mathrm{s}$ ). Groutability is also restricted when sediment particles less than $75 \mu \mathrm{m}$ are present. Sediments having greater than approximately $20 \%$ of these fine particles are generally not groutable, and difficulty in grouting starts at between $5 \%$ and $10 \%$ of fine particles. Verification of injected grout placement and the success in covering the desired target through use of multiple coalescing injections will likely be needed. These limitations and issues may restrict the viability of grouting for many Hanford Central Plateau deep vadose zone applications. The most appropriate target for permeation grouting would be high permeability zones where the largest grout penetration distances could be achieved.

In summary, application of in situ grouting for the Hanford Central Plateau deep vadose zone is limited by several factors and would be best applied to small target zones and high permeability layers to limit flux of water through contaminated zones. However, like many in situ technologies, in situ grouting may be viable in some situations if applied to targets that are suitable to its use as part of an overall solution. Thus, future feasibility studies would benefit by identifying specific targets for application of grouting in conjunction with other techniques rather than consideration of grouting as a single solution. 


\section{Acronyms and Abbreviations}

$\begin{array}{ll}\text { DOE } & \text { U.S. Department of Energy } \\ \text { Hdb } & \text { surface backfill material } \\ \text { Hf1 } & \text { Hanford formation - unit 1 } \\ \text { Hf2 } & \text { Hanford formation - unit } 2 \\ \text { Hf3 } & \text { Hanford formation - unit } 3 \\ \text { ILAW } & \text { Immobilized Low-Activity Waste Site }\end{array}$




\section{Contents}

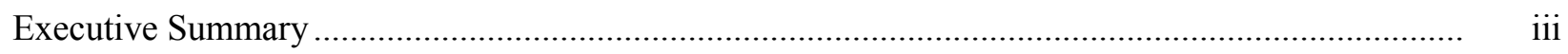

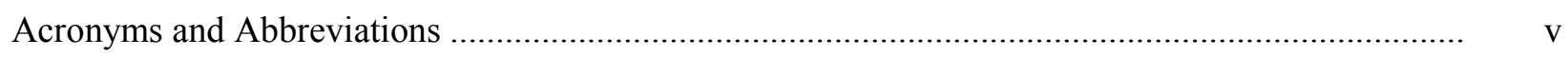

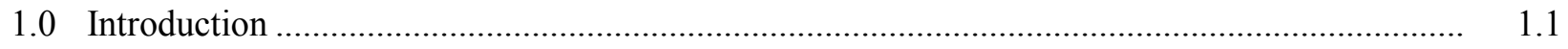

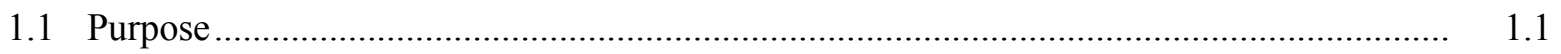

1.2 Scope, Report Contents, and Organization ............................................................... 1.1

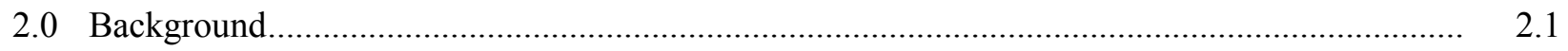

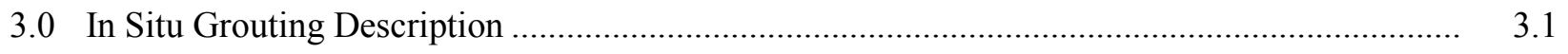

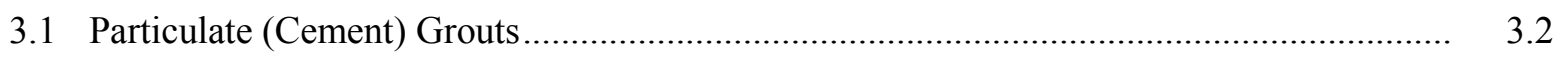

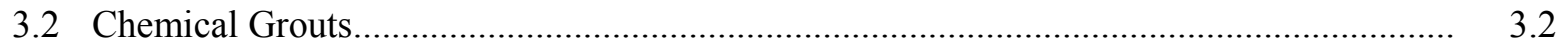

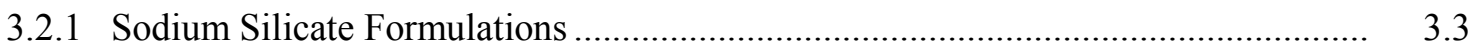

3.2.2 Colloidal Silicate Grout.............................................................................. 3.3

3.2.3 Acrylamide Grouts ....................................................................................... 3.4

3.2.4 Other Chemical Grouts............................................................................ 3.4

3.3 Permeation Injection of Chemical Grouts ................................................................

3.3.1 Grout Injection Process ................................................................................ 3.4

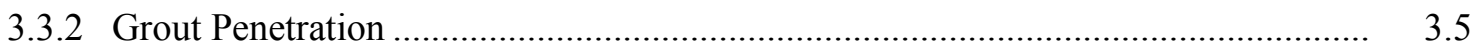

4.0 Assessment of Permeation Grouting for Hanford Vadose Zone Applications ..........................

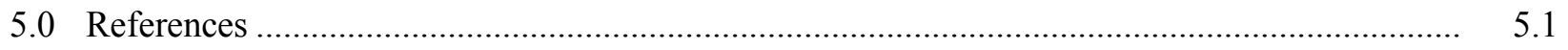

Appendix - Derivation of Equations to Estimate Grout Penetration............................................... A.1 


\section{Figures}

2.1 The Central Plateau Encompasses the 200 East and 200 West Areas of the Hanford Site........... 2.1

2.2 Generalized Central Plateau Geologic Cross Section Through the Hanford Site....................... 2.2

3.1 Viscosity as a Function of Time Using Equation 3.1 with Parameters from Table 3.1 ….......... 3.6

3.2 Injection Pressure and Radial Distance Estimates for Cylindrical Flow into a Layer 0.3-m Thick Based on Equations 3.1 and 3.2 and the Parameter Values in Table 3.1 .............. 3.8

3.3 Injection Pressure and Radial Distance Estimates for Spherical Flow from a Point Injection Source Based on Equations 3.1 and 3.3 and the Parameter Values in Table 3.1 ......... $\quad 3.8$

\section{Tables}

2.1 Representative Hydraulic Conductivity Values for the 200 West Area Vadose Zone Hanford Formation

2.2 Representative Hydraulic Conductivity Values for the 200 East Area Vadose Zone Hanford Formation

3.1 Parameters for Equations 3.1, 3.2, and 3.3

3.6 


\subsection{Introduction}

The Deep Vadose Zone Treatability Test Plan for the Hanford Central Plateau (DOE/RL 2008) identifies in situ grouting as a potential remediation technology for the deep vadose zone. There are uncertainties associated with applying in situ grouting to contaminants in the deep vadose zone at the Hanford Central Plateau, and additional information about grouting is needed to support future feasibility studies. Therefore, the Deep Vadose Zone Treatability Test Plan for the Hanford Central Plateau (DOE/RL 2008) includes a planned effort to evaluate in situ grouting. This report represents the first step in this evaluation effort.

There are multiple types of grout/binding materials and emplacement techniques that have been developed and demonstrated. Jet grouting and permeation grouting are two general categories potentially applicable for subsurface contaminant applications at the Hanford Site. Jet grouting uses high-energy emplacement of cement or chemical grout materials whereby the sediment is displaced and mixed with the grouting material. Jet grouting is a well-established technology for shallow applications and use for the deep vadose zone can be extrapolated from the shallow zone practices. Because jet grouting information is readily available for use in feasibility studies, this evaluation focuses on permeation grouting for application in the deep contaminated vadose zone. Permeation grouting is the injection of a liquid grout that fills the natural porosity and then gels to form a solid void-filling material. While permeation grouting is a relatively mature technology for many applications, there are uncertainties associated with using this technique for in situ contaminant stabilization in the deep vadose zone.

\subsection{Purpose}

The purpose of this report is to evaluate the efficacy of in situ permeation grouting as an approach that can be used to decrease contaminant (especially technetium and uranium) mobility in the Hanford Central Plateau deep vadose zone sediments.

\subsection{Scope, Report Contents, and Organization}

Although permeation grouting is a mature technology, identification of an appropriate grouting configuration, grout penetration in deep vadose sediments, and verification of proper placement are the principal challenges to implement this in situ grouting technology. An initial evaluation of in situ permeation grouting was conducted with the goal of providing information for use in subsequent feasibility studies for the Hanford Site deep vadose zone. The focus of this initial evaluation was to review candidate permeation grout materials/formulations and techniques for their application to the Hanford Site 200 Area and model grout penetration as a function of the physical properties of candidate materials and example subsurface properties.

The report contains background information describing the overall targets for vadose zone remediation and Hanford Central Plateau geology relevant to in situ permeation grouting (Section 2.0). Permeation grout materials, injection processes, and an evaluation of grout penetration are provided in Section 3.0. The report concludes with an assessment of permeation grouting for application to the Hanford Central Plateau deep vadose zone (Section 4.0). 


\subsection{Background}

Nearly 2 trillion liters (450 billion gallons) of liquid has been released into the vadose zone at the Hanford Site (DOE/RL 2008). Much of this liquid waste discharge into the vadose zone occurred in the Central Plateau (Figure 2.1). This practice resulted in large-scale contamination of the vadose zone and groundwater underlying the Central Plateau. Some of this contamination remains in the vadose zone and has the potential to contaminate groundwater in the future. The Central Plateau is an area of roughly $200 \mathrm{~km}^{2}\left(75 \mathrm{mi}^{2}\right)$ with approximately 800 waste sites. These waste sites cover $16 \mathrm{~km}^{2}\left(6 \mathrm{mi}^{2}\right)$ near the center of the plateau. The U.S. Department of Energy (DOE) is proceeding with treatability testing and a remedial investigation/feasibility study to address deep vadose zone contamination in the Central Plateau.

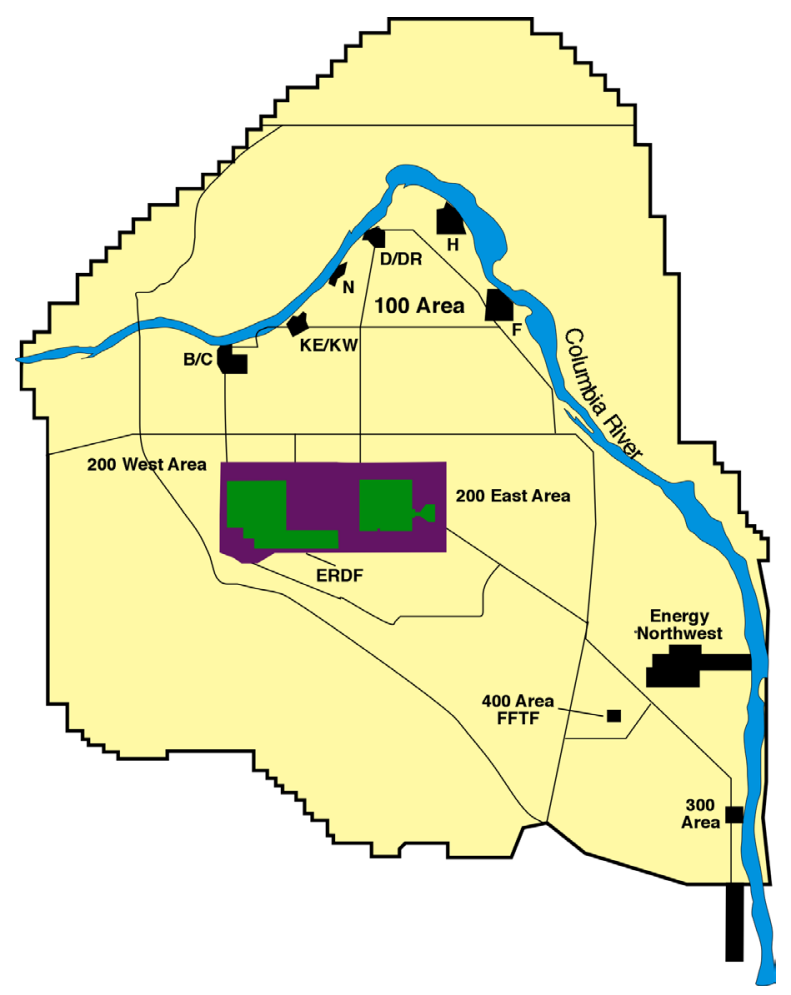

Figure 2.1. The Central Plateau (shown in purple, an area of approximately $75 \mathrm{mi}^{2}$ ) Encompasses the 200 East and 200 West Areas of the Hanford Site

The vadose zone is the region of the subsurface that extends from ground surface to the water table. The vadose zone beneath the Central Plateau ranges in thickness from about $50 \mathrm{~m}(164 \mathrm{ft})$ in the western portion of the 200 West Area to $104 \mathrm{~m}(341 \mathrm{ft})$ in the southern part of the 200 East Area (Last et al. 2009). Additional details of the Hanford Site subsurface hydrogeology are available in DOE/RL (2008). A generalized geologic cross-section of the Central Plateau is shown in Figure 2.2. 


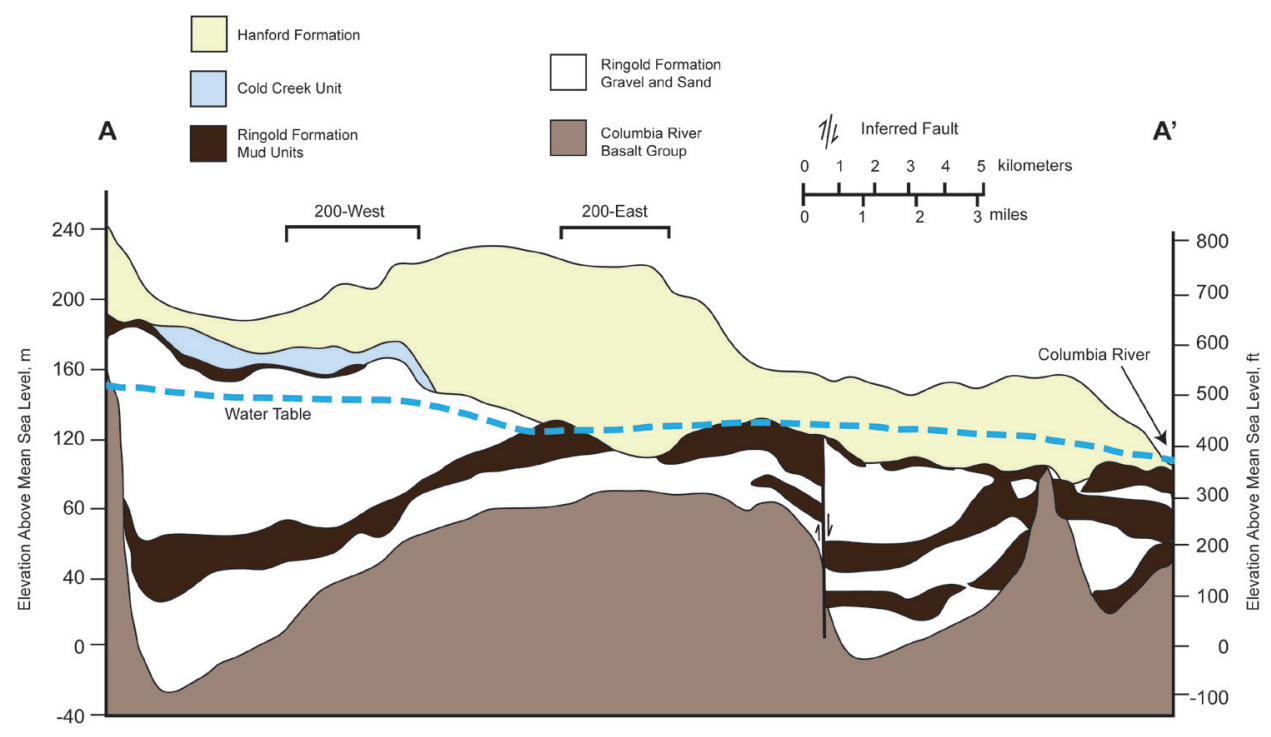

Figure 2.2. Generalized Central Plateau Geologic Cross Section Through the Hanford Site (after Hartman 2000)

The major stratigraphic units making up the vadose zone include the following:

- Surface wind-deposited sand and silt deposits

- Unconsolidated sand and gravel of the Hanford formation

- Silt and carbonate-cemented layers of the Cold Creek Unit

- Semi-consolidated sand and gravel of the Ringold Formation.

The vadose zone in the 200 East Area consists almost entirely of the Hanford formation. The vadose zone in the 200 West Area contains three major formations: the Hanford formation, the Cold Creek Unit, and the Ringold Formation. Only the Hanford formation is evaluated for permeation grouting because the Cold Creek Unit is predominantly low permeability silt material, and the expense of drilling through the Cold Creek Unit and to significant depth is assumed to preclude grouting in the underlying Ringold Formation (direct push, cone penetrometer, and related techniques have not effectively penetrated the Cold Creek Unit).

As discussed in subsequent sections of this report, the key subsurface sediment properties that control the efficacy of permeation grouting are the permeability and the particle-size distribution. Representative hydraulic conductivity values for the Hanford Central Plateau vadose zone hydrologic units have been compiled by Last et al. (2009). The representative hydraulic conductivity values of these units are summarized in Table 2.1 for the 200 West Area and in Table 2.2 for the 200 East Area. The saturated hydraulic conductivity values listed in Tables 2.1 and 2.2 are based on an averaging scheme and may not reflect the values beneath a specific waste site. Additionally, thin lenses that have been shown to promote lateral spreading and "ponding" of contaminants within the hydrologic units shown in the tables may have properties different from the average values. For example, thin, high-silt fraction lenses are a typical feature within the Hanford formation. 
Table 2.1. Representative Hydraulic Conductivity Values for the 200 West Area Vadose Zone Hanford Formation

\begin{tabular}{lc}
\hline Hydrologic Unit ${ }^{1}$ & $\begin{array}{c}\text { Saturated } \\
\text { Hydraulic } \\
\text { Conductivity } \\
(\mathrm{cm} / \mathrm{s})\end{array}$ \\
\hline Hdb (Bf) & $5.98 \mathrm{E}-04$ \\
Hf1 (Hcs) & $1.09 \mathrm{E}-03$ \\
Hf2 (Hfs) & $3.67 \mathrm{E}-05$ \\
Hf3 (Hss) & $1.91 \mathrm{E}-05$ \\
\hline${ }^{1}$ Hydrologic unit symbol in parentheses is \\
the abbreviation used in Last et al. (2009). \\
Hdb = surface backfill material \\
Hf1 = Hanford formation - unit 1 \\
Hf2 = Hanford formation - unit 2 \\
Hf3= Hanford formation - unit 3 \\
\hline
\end{tabular}

Table 2.2. Representative Hydraulic Conductivity Values for the 200 East Area Vadose Zone Hanford Formation

\begin{tabular}{|c|c|}
\hline Hydrologic Unit ${ }^{1}$ & $\begin{array}{c}\text { Saturated } \\
\text { Hydraulic } \\
\text { Conductivity } \\
(\mathrm{cm} / \mathrm{s})\end{array}$ \\
\hline $\mathrm{Hdb}(\mathrm{Bf})$ & $5.98 \mathrm{E}-04$ \\
\hline Hf1 (Hcs) & 5.32E-03 \\
\hline Hf2 (Hfs) & $2.25 \mathrm{E}-03$ \\
\hline Hf3 (Hg) & $3.30 \mathrm{E}-04$ \\
\hline \multicolumn{2}{|c|}{$\begin{array}{l}{ }^{1} \text { Hydrologic unit symbol in parentheses is } \\
\text { the abbreviation used in Last et al. }(2009) \text {. } \\
\text { Hdb = surface backfill material } \\
\text { Hf1 }=\text { Hanford formation - unit } 1 \\
\text { Hf2 = Hanford formation - unit } 2 \\
\text { Hf }=\text { Hanford formation - unit } 3\end{array}$} \\
\hline
\end{tabular}

There are a very large number of particle-size distribution data sets for the Hanford Site. However, these data have not been compiled and evaluated to establish representative values. The fraction of particles smaller than $75 \mu \mathrm{m}$ (\#200 mesh) is of most importance to permeation grouting (Vipulanandan and Ozgurel 2009; Karol 1990). Several reports, as detailed below, were reviewed to identify examples of particle-size distributions across the Hanford Central Plateau.

At the 200 East Area, the entire vadose zone is generally within the Hanford formation. In the southern portion of the 200 East Area, particle-size distribution data were compiled as part of charac- 
terization of the Immobilized Low-Activity Waste Site (ILAW) ${ }^{1}$ (Valenta et al. 2000). These data (78 samples) show an average of $7 \%$ particles smaller than $75 \mu \mathrm{m}$ with a standard deviation of $4 \%$ and a range from $0 \%$ to 23\%. Data from the B Tank Farm in the northern 200 East Area were compiled (Serne et al. 2008a). These data (42 samples) show an average of $15 \%$ particles smaller than $50 \mu \mathrm{m}$, with a standard deviation of $6 \%$ and a range from $2.8 \%$ to $26 \%$ (excluding a relatively thick silt zone encountered in the $\mathrm{H} 2$ unit at well 299-E33-12). Particle-size data are also reported for the BC Cribs and Trenches site (Serne et al. 2009). In 21 samples from borehole C5923 at the BC Cribs and Trenches site, the average distribution of particles smaller than $75 \mu \mathrm{m}$ was about $15 \%$. The fines content (passing the \#230 sieve, $\sim 63 \mu \mathrm{m}$ ) ranged from $3.5 \%$ to $21 \%$ with a mean of $10 \%$. In the C5924 borehole at this same site, the fines content (passing the \#230 sieve) ranged from $1.4 \%$ to $10.8 \%$ with a mean of $5 \%$.

At the 200 West Area, Hanford formation particle-size data are available for 9 samples from slant boreholes installed beneath the SX-108 Tank (Serne et al. 2002). All of these samples show substantially greater than $20 \%$ particles smaller than $75 \mu \mathrm{m}$ (range of $32 \%$ to $56 \%$ ). Nearby in the SX Tank Farm at well 299-W23-19, data (31 samples) show an average of 9\% particles smaller than $75 \mu \mathrm{m}$ with a standard deviation of $7 \%$ and a range from $1.2 \%$ to $23 \%$ (Serne et al. 2008b).

\footnotetext{
${ }^{1}$ The ILAW site has been renamed as the Integrated Disposal Facility (IDF) in current Hanford Site literature.
} 


\subsection{In Situ Grouting Description}

Grout injection attempts to sequester subsurface contaminants by physically or chemically binding or encapsulating contaminants. There are multiple types of grout/binding materials and emplacement techniques that have been developed and demonstrated (USACE 1995; Bolisetti 2005; Karol 1990). Jet grouting and permeation grouting are two general categories potentially applicable for subsurface contaminant applications at the Hanford Site. Jet grouting uses high-energy emplacement of cement or chemical grout materials whereby the sediment is displaced and mixed with the grouting material. Jet grouting is a well-established technology for shallow applications and its use for the deep vadose zone can be extrapolated from the shallow zone practices. Jet grouting information is readily available for use in feasibility studies; for example, as described in the recent feasibility study for Operable Unit 7-13/14 at the Idaho National Laboratory Site (Holdren et al. 2007). While Holdren et al. (2007) evaluated jet grouting for shallow in situ stabilization of waste, most of the information-except for subsurface access cost-is directly pertinent to application in the deep vadose zone. This evaluation herein focuses on permeation grouting for application in the deep contaminated vadose zone, although the basic conceptual applications could also be implemented using jet grouting. Permeation grouting is the injection of a liquid grout that fills the natural porosity and then gels to form a solid void-filling material. While permeation grouting is a relatively mature technology for many applications, there are uncertainties with applying grouting for in situ contaminant stabilization (Kaback et al. 2006).

Several DOE sites, including the Hanford Site, Oak Ridge Site, Brookhaven National Laboratory, Idaho National Laboratory Site, Savannah River Site, and Sandia Site have evaluated, tested, and/or implemented in situ grouting for shallow waste isolation applications as summarized below. In situ grouting has been evaluated at the Hanford Site for application to waste site isolation (e.g., near surface formation of in situ waste barriers) through a number of efforts in the 1990s (e.g., Persoff et al. 1994; Dwyer 1994; Heiser et al. 1994; Heiser and Dwyer 1997; DOE/RL 1995). Heiser and Dwyer (1997) provide laboratory and field data for jet grouting techniques applied to shallow waste isolation at the Hanford Site and Brookhaven National Laboratory. In situ permeation grouting using colloidal silica to develop a hydraulic barrier was evaluated and tested for application at Brookhaven National Laboratory (Moridis et al. 1999), including a significant program effort led by Lawrence Berkeley National Laboratory (Finsterle et al. 1994; Persoff et al. 1995, 1999; Moridis et al. 1995, 1996a, 1996b). Shallow permeation grouting was conducted at the Oak Ridge Site to reduce hydraulic conductivity (ORNL 1997). At the Oak Ridge Site, jet injection of standard and microfine cement grout into waste trench material improved soil stability but did not create low hydraulic conductivity conditions (Francis et al. 1993). Other efforts at the Oak Ridge Site included injection of a polyacrylamide grout into a waste trench that enhanced soil stability and had a moderate (2 orders of magnitude) impact on lowering the hydraulic conductivity (Spalding and Fontaine 1992). Detailed evaluation and treatability testing for in situ grouting of waste sites was completed at Idaho National Laboratory demonstrating the potential viability of grouting to stabilize waste in near-surface sites (Loomis et al. 2003). Holdren et al. (2007) provided a thorough review of in situ grouting for shallow waste sites at Idaho National Laboratory and retained this technology as a potential alternative in a feasibility study for Operable Unit 7-13/14 based on the likely ability of the technology to stabilize the waste and reduce hydraulic conductivity. The Savannah River Site has implemented in situ grouting for shallow waste sites such as the F Area seepage basins (DOE 1999). 
Although the discussion above provides some indication of the maturity of in situ grouting, application of these techniques to depths that are greater than $30 \mathrm{~m} \mathrm{(100} \mathrm{ft)} \mathrm{for} \mathrm{contaminant} \mathrm{control} \mathrm{in} \mathrm{the} \mathrm{deep}$ vadose zone have not been demonstrated. In the following sections, two major categories of permeation grout, particulate (cement)-based grouts and chemical grouts, are described. The grout injection process is then summarized, followed by an assessment of grout penetration into subsurface vadose zone sediments.

\subsection{Particulate (Cement) Grouts}

Cement grouts use Portland cement as the primary component. Portland cement is a mixture of preprocessed mineral solids pulverized, fired, and ground into a fine solid dust. This product is combined with up to 5\% gypsum and mixed with water and small quantities of additives to form a flowable mixture of solids and water composing a suspended solids grout. Depending on the proportion of water in the mixture, particulate grouts have a range of viscosities.

The particle-size distribution of solids in cement grouts controls the ability of the grout to penetrate fine formation openings. Nominally, the smallest grout solid should be no larger than the formation void dimension desired to be filled. For cement grouts, emplacement can become an issue for the finely textured regions of the deep vadose zone because of particle filtration. Microfine or ultrafine cement grouts incorporate micron-scale solids in the mix. For example, the particle-size distribution of microfine slag cement is characterized by $98 \%$ below 7 microns and 50\% below 3 microns, and ultrafine Portland cement and blast furnace slag cement is characterized by $98 \%$ below 10 microns and $50 \%$ below 4 microns. In comparison to typical cement grout mixtures, microfine cement mixtures allow for greater penetration. However, grout penetration of even microfine cement would only be appropriate for coarse sand or gravel layers with no fine sediments less than about 100- $\mu$ m diameter. As such, cement grouts have very limited applicability to the Hanford Central Plateau deep vadose zone for permeation grouting because the Hanford formation sediments in general have between 7 and $20 \mathrm{wt} \%$ particles finer than $75 \mu \mathrm{m}$ as described in Section 2.0.

\subsection{Chemical Grouts}

A chemical grout is a solution comprised of a binder (other than Portland cement) that reacts in place to form a gel or solid after injection into a porous subsurface soil, sediment, or rock volume. Chemical grouts do not need to contain mineral solids in suspension, and therefore their delivery in the subsurface is not limited by particle filtration. Instead, delivery is primarily a function of grout viscosity and gelling time. Viscosity directly impacts injection pressure and distribution of grout to small pores based on the properties of viscous fluid flow. Gelling time impacts penetration distance because as the grout material gels, viscosity increases significantly and the material then becomes nonfluid. There are a variety of materials that have been used for in situ grouting. These include the following: sodium silicate formulations, colloidal silicate, acrylics/acrylamides, urethanes, lignosulfates-lignosulfonates, phenoplasts, and aminoplasts. A summary of each of these materials is provided below. An overall description of chemical grouts is provided in Bolisetti (2005) and the U.S. Army Corps of Engineers (1995), although colloidal silica grouts are not included in the U.S. Army Corps of Engineers document. Limitations for grouting relative to particle size and permeability are also discussed in multiple publications (e.g., Dwyer 1994; Ozgurel and Vipulanandan 2005; Vipulanandan and Ozgurel 2009; Karol 1990). Two chemical grout systems dominate current applications and research: silicate- and acrylic-based grouts. 


\subsubsection{Sodium Silicate Formulations}

Liquid solutions of sodium silicate $\left(\mathrm{SiO}_{2} \bullet \mathrm{Na}_{2} \mathrm{O}\right)$ are alkaline. When mixed with an appropriate reagent, the $\mathrm{pH}$ of the sodium silicate liquid is neutralized and the liquid gels (USACE 1995). Testing of a sodium silicate grout uniformly distributed and gelled in a fine sand showed poor permeability reduction capability with a final grouted permeability of about $1 \times 10^{-14} \mathrm{~m}^{2}$ (hydraulic conductivity of $\left.1 \times 10^{-5} \mathrm{~cm} / \mathrm{s}\right)($ Boldocsi 1991), which may be insufficient for application of grout as a hydraulic barrier. For in situ grouting application at the Hanford Site, the grouting material would consist of sodium silicate and a neutralization reagent that reacts slowly so the grout can be injected as a relatively low-viscosity fluid that gels over time, usually over a period of tens of minutes to a few hours. The viscosity of a silicate grout is proportional to the silicate concentration where a grout with about $50 \%$ by volume silicate has a viscosity of about $5 \mathrm{cP}$. The silicate solution concentration may vary from 10 to $70 \%$ by volume, depending on the result desired. Grouts containing 35\% or more silicate by volume would be necessary for application at the Hanford Site because they are more resistant to deterioration by wetting and drying than low-silicate grouts. In addition, silicate grout may shrink as the gel dries; this effect would need to be tested for Hanford Site applications. Sodium silicate grouts exhibit syneresis, which is the process of exudation of liquid (generally water) from set gel due to the tightening of the grout material structure. Of the sodium silicate grouting processes, the Malmberg system (USACE 1995) is most appropriate for the Hanford Site vadose zone because it can be formulated to be stable in unsaturated sediment. The primary limitation for application to the Hanford Site would be for sediments with highly alkaline pore water because gelling of the Malmberg system grout is inhibited at high $\mathrm{pH}$. Sediments with low $\mathrm{pH}$ pore water may also be problematic because gelling is accelerated, and consequently, penetration distance would be reduced. Although sodium silicate grouts have properties favorable for application in the vadose zone, their application would be for fine sand through gravel layers with no fine sediments less than approximately $100-\mu \mathrm{m}$ diameter.

\subsubsection{Colloidal Silicate Grout}

Colloidal silica grout was developed as an alternative to sodium silicate grouts targeting a lower initial viscosity, absence of syneresis, and better gel time control (Finsterle et al. 1994; Moridis et al. 1999; Kim and Corapcioglu 2002a, 2002b). Permeability measurements for a field test of colloidal silica grout showed that a final grouted permeability of about $1 \times 10^{-16} \mathrm{~m}^{2}$ (hydraulic conductivity of $1 \times 10^{-7} \mathrm{~cm} / \mathrm{s}$ ) are achievable (Moridis et al. 1999). For in situ grouting application at the Hanford Site, the grouting material would consist of colloidal silica and a reactant to initiate gelling that reacts slowly so the grout can be injected as a relatively low-viscosity fluid that gels over time, ideally over a few hours. The grout solution would need to be tailored to the sediment and pore-water chemistry to control gelling. For example, in an early study of colloidal silica grouting at the Hanford Site, Persoff et al. (1994) found that gelling occurred prematurely due to exchange of sodium in the gelling solution with naturally occurring divalent cations in the Hanford Site sediment. If colloidal silica grout were injected in contaminated regions, the potential impact of contaminated pore water and sediment chemistry may also need to be evaluated. There are potential solutions to the premature gelling issue, but site-specific conditions would need to be considered. The viscosity of a silicate grout is proportional to the silicate concentration, but colloidal silica grouts can generally be formulated with a starting viscosity of 3-15 cP. Colloidal silica has been tested and modeled for use in environmental applications (Moridis et al. 1999; Kim and Corapcioglu 2002a, 2002b; Durmusoglo and Corapcioglu 2000) such that the performance could be reasonably evaluated for Hanford Site applications in a feasibility study. 


\subsubsection{Acrylamide Grouts}

Acrylamide grouts were replaced by acrylate grouts for a brief period because acrylate grouts are less toxic. Acrylamide grouts have returned to predominant use because the toxicity can now be addressed through improved health and safety procedures (Ozgurel and Vipulanandan 2005) and acrylamide grouts have better properties than acrylate grouts. Acrylamide grouts gel by polymerization reactions where the gel time can be varied based on the grout formulation with gel times up to a few hours. Testing of an acrylamide grout uniformly distributed and gelled in a fine sand showed a grouted permeability of about $1 \times 10^{-19} \mathrm{~m}^{2}$ (hydraulic conductivity of $1 \times 10^{-10} \mathrm{~cm} / \mathrm{s}$ ) (Boldocsi 1991), sufficient for application as a hydraulic barrier. Of importance to Hanford Site vadose zone applications, these grouts can be formulated for very low initial viscosity (1-2 cP) and long gel times ( $>1 \mathrm{hr}$ ) (Krizek et al. 1992). The low viscosity and long gel time enable this grout to penetrate finer-grained sediments better than other chemical grouts. The lower limit of applicability would be for silty sands with less than about $20 \%$ fraction of particles that are less than about $75-\mu \mathrm{m}$ diameter. The gelled grouts are insoluble in typical vadose zone pore-water chemistries and likely suitable for vadose zone application.

\subsubsection{Other Chemical Grouts}

Urethane, lignin-based, phenoplasts, and aminoplasts are other types of chemical grouts. None are likely applicable to the Hanford Site vadose zone. Urethane grouts form gels or foams depending on their contact with water and have relatively high viscosity (greater than $50 \mathrm{cP}$ ). Two additional drawbacks are the toxicity and flammability for some urethane formulations. Lignin-based gels can be formed, but contain solids and are not durable. Phenoplasts and aminoplasts are not expected to be durable in the dry vadose zone conditions present at the Hanford Site. Molten wax has also been conceptually examined as a permeation grout for deep vadose zone applications (Carter and Cooper 2008) and is anticipated to behave similarly to grout materials such as acrylamide but with different solidification characteristics. With additional development, molten wax could be considered as an alternative to acrylamide- or silicatebased grouting materials.

\subsection{Permeation Injection of Chemical Grouts}

The following sections summarize the grout injection process and assess grout penetration distance for vadose zone sediments.

\subsubsection{Grout Injection Process}

Typical placement of grout into the subsurface is conducted through a borehole or pushed probe installed vertically into the zone of concern (USACE 1995; Karol 1990). Installation of grout using slant (Persoff et al. 1994; Moridis et al. 1999) or horizontal wells (Kim and Corapcioglu 2002b; Durmusoglo and Corapcioglu 2000; Dwyer 1994) has also been evaluated. The fluid grout mixture is injected under pressure using several general configurations for releasing the grout into the subsurface. Relatively simple lances on injection push rods provide openings for grout flow over a selected interval (Moridis et al. 1999). Horizontal well configurations have been tested; for example, with injection using a packer system and annular grouted well configuration to make grout flow more uniformly along the target interval (Dwyer 1994). Specific injection equipment will vary depending on the grouting vendor. 
Generally, multiple overlapping injections are deposited along a line or over an area to cover the zone of interest.

\subsubsection{Grout Penetration}

General limits for use of permeation grouts are provided in the technical literature (e.g., Dwyer 1994; Ozgurel and Vipulanandan 2005; Vipulanandan and Ozgurel 2009; Karol 1990; Bolisetti 2005) and are based on sediment permeability and particle size. Groutability of sediments becomes difficult at permeabilities less than about $1 \times 10^{-12} \mathrm{~m}^{2}$ (a hydraulic conductivity of about $1 \times 10^{-3} \mathrm{~cm} / \mathrm{s}$ ). Groutability is also restricted when sediment particles less than $75 \mu \mathrm{m}$ are present. Sediments having greater than approximately $20 \%$ of these fine particles are generally not groutable, and difficulty in grouting starts at between $5 \%$ and $10 \%$ of these fine particles. Using the hydraulic conductivity information in Tables 2.1 and 2.2, permeation grouting would be most applicable to the Hf1 and Hf2 units for the Hanford Central Plateau. Particle-size distributions vary significantly with depth at the Hanford Site. However, as shown by the example data in Section 2.0, Hf1 and Hf2 vadose zone sediments containing greater than 5\% fine $(<75 \mu \mathrm{m})$ particles, with some containing greater than $20 \%$ fine particles, can be encountered in the Hanford formation sands and gravels. Variations in the fines content with depth and related permeability distribution will impact grout emplacement.

Grout penetration distance can be estimated as part of evaluating implementation requirements (e.g., spacing of injection locations). Chemical grout injection is a three-dimensional process and design typically relies on empirical relationships (USACE 1995; Karol 1990) or numerical simulation (Kim and Corapcioglu 2002a, 2002b; Moridis et al. 1999). For gelling grouts such as sodium silicate, colloidal silicate, and acrylamide grouts, a key factor in predicting the grout penetration distance is the grout viscosity as a function of time. Grout chemistry can be manipulated to control the gelling reactions and is a key design factor for a specific application. As summarized by Bolisetti (2005), several equation forms have been used for describing the grout viscosity as a function of time and other factors (Honma 1984; Finsterle et al. 1994; Kim and Corapcioglu 2002a). As an example, the viscosity of the grout can be described by Equation 3.1 (Finsterle et al. 1994), as was applied by Bolisetti et al. (2007) and Moridis et al. (1999) for simulating colloidal silica grout injection:

$$
\mu_{g e l}=a_{1}+a_{2} e^{a_{3} t}
$$

where $a_{1}, a_{2}, a_{3}$ are fitting coefficients based on laboratory data and grout material information and $\mu_{\text {gel }}$ is the viscosity of the injected silica grout. Figure 3.1 shows a plot of viscosity versus time using Equation 3.1 and grout parameters derived for a colloidal silicate grout application at Brookhaven National Laboratory (Persoff et al. 1998). Acrylamide grouts can be formulated to retain a viscosity very near the initial viscosity until they gel (Krizek et al. 1992). While there can be some variation in the gelling response for different grout formulations, gelling eventually leads to viscous and then nonfluid gel that limits the extent of grout penetration due to buildup of injection pressure. Analytical scoping calculations for cylindrical (Equation 3.2) and spherical (Equation 3.3) grout penetration were developed based on Darcy's Law and incorporating temporal variations in grout viscosity from Equation 3.1 and with parameters as described in Table 3.1. Derivations of these equations are shown in the Appendix. 


$$
\begin{gathered}
P_{o}=P+Q\left[\frac{\left(\frac{Q t}{n h \pi}\right)^{1 / 2}-R_{o}}{2 \pi h\left[\frac{k \rho g}{\left.\left(a_{1}+a_{2} e^{\left(a_{3} t\right)}\right)\right]\left[\frac{Q t}{n h \pi}\right]^{1 / 2}}\right]}\right. \\
P_{o}=P+Q\left[\frac{\left(\frac{0.75 Q t}{n \pi}\right)^{1 / 3}-R_{o}}{4 \pi\left[\frac{k \rho g}{\left(a_{1}+a_{2} e^{\left(a_{3} t\right)}\right)}\right]\left[\left[\frac{0.75 Q t}{n \pi}\right]^{1 / 3}\right]^{2}}\right]
\end{gathered}
$$

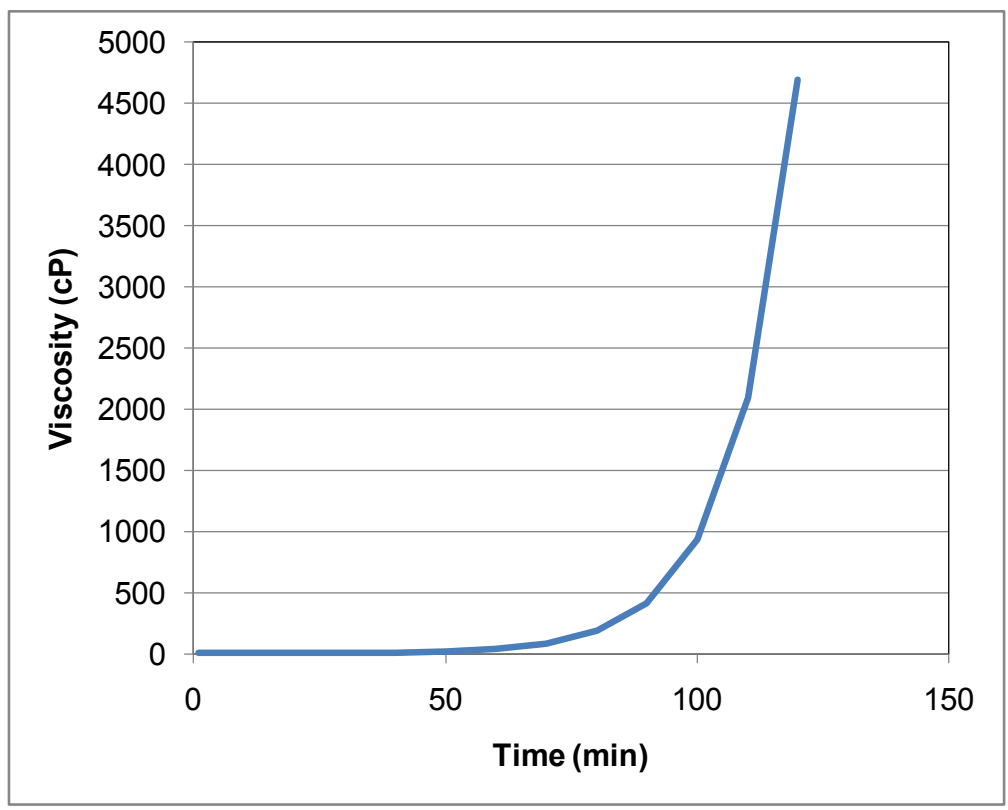

Figure 3.1. Viscosity as a Function of Time Using Equation 3.1 with Parameters from Table 3.1. The initial viscosity of the colloidal silica grout is $3.5 \mathrm{cP}$.

Table 3.1. Parameters for Equations 3.1, 3.2, and 3.3

\begin{tabular}{llc}
\hline Parameter & \multicolumn{1}{c}{ Description } & \multicolumn{1}{c}{ Value in Example } \\
\hline $\mathrm{P}_{\mathrm{o}}$ & Injection pressure (pressure at Ro) $(\mathrm{m})$ & Dependent variable \\
$\mathrm{P}$ & $\begin{array}{l}\text { Pressure at outer edge of grout (assumed to be atmospheric for vadose } \\
\text { zone applications) }(\mathrm{m})\end{array}$ & 10.34 \\
$\mathrm{Q}$ & Grout injection flow rate $\left(\mathrm{m}^{3} / \mathrm{s}\right)$ & Multiple inputs \\
$\mathrm{t}$ & Time $(\mathrm{s})$ & Independent variable \\
$\mathrm{n}$ & Porosity & 0.3 \\
$\mathrm{~h}$ & Cylinder height assumed for grout injection (user input based on & 0.3 \\
& stratigraphic information) $(\mathrm{m})$ & \\
$\mathrm{R}_{\mathrm{o}}$ & Grouting injection rod radius $(\mathrm{m})$ & 0.015 \\
$\mathrm{k}$ & Sediment hydraulic permeability $\left(\mathrm{m}^{2}\right)$ & Multiple inputs \\
\hline
\end{tabular}


Table 3.1. (Cont.)

\begin{tabular}{llc}
\hline$\rho$ & Grout density $\left(\mathrm{kg} / \mathrm{m}^{3}\right)$ & 1000 \\
$\mathrm{~g}$ & Gravitational acceleration $\left(\mathrm{m} / \mathrm{s}^{2}\right)$ & 9.8 \\
$a_{1}$ & Viscosity equation fitting parameter for Equation $3.1(\mathrm{~kg} / \mathrm{m} \mathrm{s})$ & 0.00322 \\
$a_{2}$ & Viscosity equation fitting parameter for Equation $3.1(\mathrm{~kg} / \mathrm{m} \mathrm{s})$ & 0.000282 \\
$a_{3}$ & Viscosity equation fitting parameter for Equation $3.1(\mathrm{~kg} / \mathrm{m} \mathrm{s})$ & 0.00135 \\
\hline
\end{tabular}

These equations enable estimation of idealized grout penetration and associated injection pressure as a function of time and input parameters. Equation 3.2 for cylindrical grout injection is useful for subsurface conditions where a distinct high permeability layer (or layers) is present with a thickness comparable to or less than the injection interval. Grout will preferentially flow into these layers and distribution would be more cylindrical, the cylinder height being equal to the layer thickness. In the absence of significant permeability contrasts, grout would flow more spherically from the injection point as described in Equation 3.3. Heterogeneity in subsurface properties-primarily permeability, particlesize distribution, and moisture content-will impact the three-dimensional nature of grout movement and cause grout distribution departing from the idealized representations of Equations 3.2 and 3.3. Additionally, gravitational forces will deform the injected volume downward, depending on the subsurface properties and grout injection parameters (Kim and Corapcioglu 2002b), especially for grouts formulated with a viscosity near that of water.

Temporal variation of grout viscosity is not the only phenomena that can limit grout penetration. As the grout gels over time, it can form gel globules that can be filtered out in the sediment and restrict the pore space for further fluid movement. The restricted pore space can lead to fingering of the fluid grout flow and associated nonuniformity in grout distribution (Bolisetti 2005). Other fluid phenomena, such as the impact of shear on gelling and fluid flow, can impact grout distribution (Bolisetti 2005). Additionally, sediment/porewater chemistry can impact grout gelling. Relevant to the Hanford Site, Persoff et al. (1994) demonstrated that divalent cations naturally found on the exchange sites in Hanford Site sediment significantly decreased gelling time for a colloidal silica grout and that alterations to the grout chemistry, such as the addition of sodium fluoride, were necessary to produce gelling times suitable for permeation grouting. These factors introduce uncertainty in grout penetration distance and uniformity.

Considering the above grout injection uncertainties and idealized nature of Equations 3.2 and 3.3, these equations can still provide for scoping level assessment of grout penetration. Example calculations were conducted using the parameter values shown in Table 3.1. For grout injection into a defined subsurface layer (e.g., higher permeability layer than surrounding sediment), Figure 3.2a shows the injection radius and pressure calculated as a function of time using Equation 3.2 for three different injection flow rates and a fixed permeability of $1 \times 10^{-11} \mathrm{~m}^{2}$. For comparison, Figure $3.2 \mathrm{~b}$ shows these same parameters for three different permeability values at a fixed injection flow rate of $0.001 \mathrm{~m}^{3} / \mathrm{s}(16$ gpm). Similarly, for grout injection into more a homogeneous subsurface where spherical flow is expected, the injection radius and pressure as a function of time for three flow rates (Figure 3.3a) and three permeability values (Figure 3.3b) were calculated using Equation 3.3. For interpretation, a maximum reasonable injection pressure of $50 \mathrm{psi}$ can be considered for a grouting depth of about $20 \mathrm{~m}$ to maintain an injection pressure of less than 1.5 times the lithostatic pressure. These figures demonstrate the general grout injection processes and highlight how penetration is limited by gelling and subsurface permeability. 

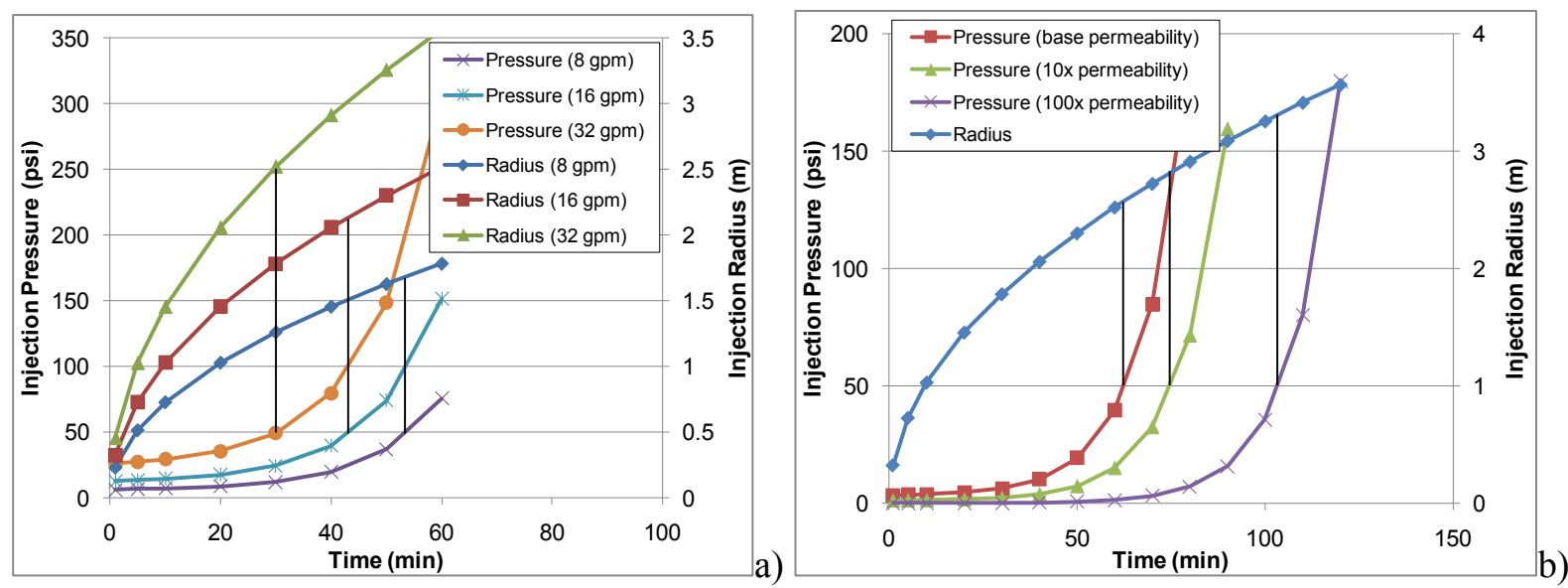

Figure 3.2. Injection Pressure and Radial Distance Estimates for Cylindrical Flow into a Layer 0.3-m Thick Based on Equations 3.1 and 3.2 and the Parameter Values in Table 3.1. a) The permeability is constant at $1 \times 10^{-11} \mathrm{~m}^{2}$ and grout injection flow rates are 8,16 , and $32 \mathrm{gpm}$, corresponding to $0.0005,0.001$, and $0.002 \mathrm{~m}^{3} / \mathrm{s}$, respectively. b) The flow rate is constant at $16 \mathrm{gpm}\left(0.001 \mathrm{~m}^{3} / \mathrm{s}\right)$ and the permeabilities are base $\left(1 \times 10^{-11} \mathrm{~m}^{2}\right)$, ten times the base $\left(1 \times 10^{-10} \mathrm{~m}^{2}\right)$, and one hundred times the base $\left(1 \times 10^{-9} \mathrm{~m}^{2}\right)$.
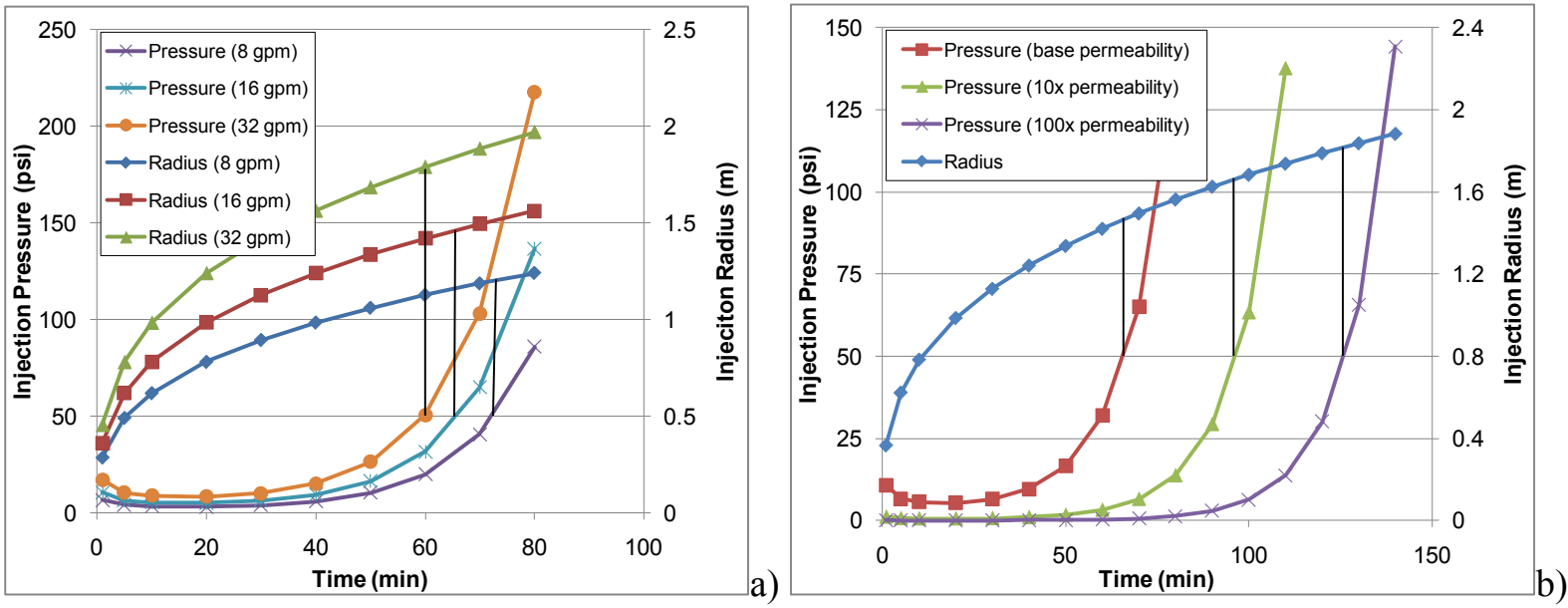

Figure 3.3. Injection Pressure and Radial Distance Estimates for Spherical Flow from a Point Injection Source Based on Equations 3.1 and 3.3 and the Parameter Values in Table 3.1. a) The permeability is constant at $1 \times 10^{-11} \mathrm{~m}^{2}$ and grout injection flow rates are 8,16 , and $32 \mathrm{gpm}$, corresponding to $0.0005,0.001$, and $0.002 \mathrm{~m}^{3} / \mathrm{s}$, respectively. b) The flow rate is constant at $16 \mathrm{gpm}\left(0.001 \mathrm{~m}^{3} / \mathrm{s}\right)$ and the permeabilities are base $\left(1 \times 10^{-11} \mathrm{~m}^{2}\right)$, ten times the base $\left(1 \times 10^{-10} \mathrm{~m}^{2}\right)$, and one hundred times the base $\left(1 \times 10^{-9} \mathrm{~m}^{2}\right)$. 


\subsection{Assessment of Permeation Grouting for Hanford Vadose Zone Applications}

In the Hanford Central Plateau, the highest concentrations of target mobile contaminants (and thus most desired for grout remediation) are anticipated to be located in horizontal spreading layers on top of or within finer-grained lenses of the subsurface, although contamination in coarser sediments may also be of concern. Two general types of grouting approaches may be applicable to address deep vadose zone contamination in the Hanford Central Plateau, as discussed below.

Grout could be injected to form a low-permeability layer above, and potentially surrounding, the contamination that deflects infiltrating moisture and thereby slows downward migration of the contaminant. This approach would decrease the contaminant flux to the groundwater by controlling moisture flux through and out of the contaminated zone. One example of this approach would be to isolate contaminated silt layers by grouting in the more permeable layers above and/or below the silt layer. The grouted-filled sediment would have grout filling the pore space between sediment grains, but voids may still be present due to incomplete filling during injection where grout injections have not coalesced to form a contiguous barrier; also, for some grouts, shrinkage over time may also cause some void formation. While a grout would not be an impermeable barrier, slowing the contaminant flux may be sufficient to meet remediation goals similarly to how other in situ remedies, such as desiccation, act to limit contaminant flux.

In some cases, grout could be injected directly into the contaminated sediment zones to encapsulate contaminants and limit contact with infiltrating water; e.g., volumetric encapsulation. In the vadose zone, permeation grouting applied to encapsulate contaminants directly is not expected to create a monolith like a grouted waste form that is prepared above ground. The injected grout would fill pore space between the sediment grains, although some void space in the grouted region may remain. Thus, volumetric encapsulation does not create an impermeable monolith, but would be expected to reduce the flux of water through the contaminated zone. With volumetric grout encapsulation, some portion of the contaminated pore water may be incorporated into the grout such that contaminant release would be related to a leaching process. However, some of the pore water and contaminants would remain separate from the grout and be associated with the sediment surfaces. This sediment/pore water contamination would be most susceptible to water infiltration through the grouted region.

The sediment size distribution and stratigraphic setting of the targeted grouting zone will control both the type of grout selected and the deployment strategy selected. Chemical grouts are likely the only suitable grouting material for permeation grouting in the deep vadose zone at the Hanford Site. In many cases for the Hanford Site deep vadose zone, a grouting approach to cover or trap contaminated zones and minimize water infiltration will be the only potentially appropriate grout application. Note that when injecting grouts, moisture contained in the region of influence can be displaced and mobilized. The amount of moisture displaced is expected to be greater for the chemical grouts, in comparison to the cement-based grouts because cement-based grouts can consume moisture as the components react during grout emplacement.

Two chemical grouts are recommended for consideration in the Hanford Site deep vadose zone: acrylamide and silicate grouts. Both materials can be formulated for relatively low injection viscosities (1-5 cP) and controlled long gelling times, are durable in the vadose zone, and may be able to penetrate 
sediment layers relevant to Hanford Site application (i.e., layers including some fine-grained sediment layers or sands containing a small percentage of silt particles). The two chemical grout candidates both have potential limitations because of voids from nonuniform injection. Void formation over time because of shrinkage may also occur under some conditions. For each of these grouts, contaminant leaching from the grout is expected to be slow, although the specific leaching rate has not been quantified. The dominant contaminant release mechanism is expected to be from contaminants that remain associated with the pore water/sediment surfaces and are transported with water infiltration through voids in the grout or where grout injections have not coalesced to form a contiguous barrier. Durmusoglo and Corapcioglu (2000) examined formation of a colloidal silica grout barrier in a bench-scale test and qualitatively showed coalescence of adjacent grout injections for both vertical and horizontal injection strategies. Field testing at Brookhaven National Laboratory showed variations in grouting coverage and resultant permeability reduction, but results were generally consistent with the numerical simulationbased design (Moridis et al. 1999). For any of these applications, grout penetration limitations and the requirement for coalescence of adjacent grouting injections will require injection intervals spaced only a meter or so apart to create a substantial hydraulic barrier. Potentially, use of acrylamide or silicate grout material formulated for a long gel time may allow for larger injection spacing with injection into layers of high permeability.

Grout penetration distance is a primary cost factor and potential physical limitation for grout application in the Hanford Central Plateau deep vadose zone. An estimate of grout penetration can be determined using the analytical approach described in this report and information about the grout gelling time. In most cases, the grout penetration distance will be small relative to the lateral size of the target treatment zone for Hanford Site applications. Additionally, grout penetration is a strong function of the subsurface sediment properties. General limits for use of permeation grouts are provided in the technical literature (e.g., Vipulanandan and Ozgurel 2009; Karol 1990) and are based on sediment permeability and particle size. Groutability of sediments becomes difficult at permeabilities less than about $1 \times 10^{-12} \mathrm{~m}^{2}$ (a hydraulic conductivity of about $1 \times 10^{-3} \mathrm{~cm} / \mathrm{s}$ ). Groutability is also restricted when sediment particles less than $75 \mu \mathrm{m}$ are present. Sediments having greater than approximately $20 \%$ of these fine particles are generally not groutable, and difficulty in grouting starts at between $5 \%$ and $10 \%$ of these fine particles. Using the hydraulic conductivity information in Tables 2.1 and 2.2, permeation grouting would be most applicable to the Hf1 and Hf2 units for the Hanford Central Plateau. Particle-size distributions vary significantly with depth at the Hanford Site. However, as shown by the example data in Section 2.0, Hf1 and Hf2 vadose zone sediments containing greater than 5\% fine $(<75 \mu \mathrm{m})$ particles, with some containing greater than $20 \%$ fine particles, are common. Variations in the fine content with depth and related permeability distribution will impact grout emplacement. Verification of injected grout placement and the success in covering the desired target through use of multiple coalescing injections will likely be needed. These limitations and issues may restrict the viability of grouting for many Hanford Central Plateau deep vadose zone applications. A similar conclusion was reached by an independent review panel (Kaback et al. 2006) that evaluated in situ grouting as an option for the Hanford Site deep vadose zone. Kaback et al. (2006) identified several issues, two of which include the following:

- Effectiveness of delivery depends upon subsurface heterogeneity, which could impact the effectiveness of the grout distribution.

- Validation and monitoring of grout performance would be extremely difficult. 
In summary, application of in situ permeation grouting for the Hanford Central Plateau deep vadose zone is limited by several factors and would be best applied to small target zones. However, like many in situ technologies, in situ grouting may be viable in some situations if applied for targets that are suitable to its use as part of an overall solution. Thus, future feasibility studies would benefit by identifying specific targets for application of grouting in conjunction with other remediation techniques rather than consideration of grouting as a single solution or for a volumetrically large application. 


\subsection{References}

Bodocsi A and MT Bowers. 1991. "Permeability of Acrylate, Urethane, and Silicate Grouted Sands with Chemicals.” Journal of Geotechnical Engineering-ASCE 117(8): 1227-1244.

Bolisetti T. 2005. Experimental and Numerical Investigations of Chemical Grouting in Heterogeneous Porous Media. Ph.D. Dissertation, University of Windsor, Ontario, Canada.

Bolisetti T, S Reitsma, and R Balachandar. 2007. "Analytical Solution for Flow of Gelling Solutions in Porous Media.” Geophysical Research Letters 34, L24401, doi:10.1029/2007GL031713.

Carter EE and DC Cooper. 2008. "Construction of Flexible Subterranean Hydraulic Barriers in Soil and Rock.” In Proceedings of Waste Management February 24-28, 2008, paper 8281, Phoenix, Arizona.

DOE. 1999. Corrective Measures Implementation/Remedial Design Report/Remedial Action Work Plan (CMI/RDR/RAWP) for the F-Area Seepage Basin (904-49G) (U). WSRC-RP-97-854, Rev. 1,

U.S. Department of Energy Idaho Operations Office, Idaho Falls, Idaho.

DOE/RL. 1995. In Situ Remediation Integrated Program FY 1994 Program Summary. DOE/RL-95-32, U.S. Department of Energy, Richland Operations Office, Richland, Washington.

DOE/RL. 2008. Deep Vadose Zone Treatability Test Plan for Hanford Central Plateau.

DOE/RL-2007-56, Rev. 0, U.S. Department of Energy, Richland Operations Office, Richland, Washington.

Durmusoglo E and MY Corapcioglu. 2000. "Experimental Study of Horizontal Barrier Formation by Colloidal Silica.” J. Environmental Engineering 126(9):833-841.

Dwyer BP. 1994. "Feasibility of Permeation Grouting for Constructing Subsurface Barriers." In 33rd Hanford Symposium on Health and Environment, In-Situ Remediation: Scientific Basis for Current and Future Technologies, Part 1, eds. GW Gee and NR Wing, pp. 3-36, Battelle, Columbus, Ohio.

Finsterle S, GJ Moridis, K Pruess, and P Persoff. 1994. Physical Barriers Formed from Gelling Liquids: 1. Numerical Design of Laboratory and Field Experiments. LBL-35113, Lawrence Berkeley National Laboratory, Berkeley, California.

Francis CW, RD Spence, T Tamura, and BP Spalding. 1993. In Situ Grouting of Low-Level Burial Trenches with a Cement-Based Grout at Oak Ridge National Laboratory. ORNL/TM-11838, Oak Ridge National Laboratory, Oak Ridge, Tennessee.

Hartman MJ, LF Morasch, and WD Webber. Hanford Site Groundwater Monitoring for Fiscal Year 2000. PNNL-13404, Pacific Northwest National Laboratory, Richland, Washington.

Heiser J, L Milian, J Clinton, and P Colombo. 1994. "Durability of Polymers for Containment Barriers." In 33rd Hanford Symposium on Health and Environment, In-Situ Remediation: Scientific Basis for Current and Future Technologies, Part 1, eds. GW Gee and NR Wing, pp. 61-86, Battelle, Columbus, Ohio. 
Heiser JH and BP Dwyer. 1997. Summary Report on Close-Coupled Subsurface Barrier Technology Initial Field Trials to Full-Scale Demonstration. BNL-52531, Brookhaven, National Laboratory, Upton, New York.

Holdren KJ, TE Bechtold, and BD Preussner. 2007. Feasibility Study for Operable Unit 7-13/14. DOE/ID-11268, Rev. 0, U.S. Department of Energy Idaho Operations Office, Idaho Falls, Idaho.

Karol RH. 1990. Chemical Grouting, 2nd ed. Marcel Dekker, New York.

Kaback DS, MH Young, TW Fogwell, SW Petersen, MD Ankeny, JMH Hendrickx, BB Looney, EP Weeks, and SE Silliman. 2006. Evaluation of Vadose Zone Treatment Technologies to Immobilize Technetium-99. WMP-27397, Rev. 1, Fluor Hanford, Richland, Washington.

Kim M and MY Corapcioglu. 2002a. "Gel Barrier Formation in Unsaturated Porous Media." J. Contam. Hydrol. 56:75-98.

Kim M and MY Corapcioglu. 2002b. "Modeling of Gel Barrier Formation by Using Horizontal Wells." J. Environmental Engineering 128(10):929-941.

Krizek RJ, DF Michel, M Helal, and RH Borden. 1992. "Engineering Properties of Acrylate Polymer Grout." Grouting, Soil Improvement and Geosynthetics, Vols. 1 and 2. Geotechnical Special Publication 30(1): 712-724.

Last GV, ML Rockhold, CJ Murray, and KJ Cantrell. 2009. Selection and Traceability of Parameters to Support Hanford-Specific RESRAD Analyses--Fiscal Year 2008 Status Report. PNNL-18564, Pacific Northwest National Laboratory, Richland, Washington.

Loomis GG, JJ Jessmore, JR Weidner, CM Miller, and AL Sehn. 2003. Final Results Report, In Situ Grouting Technology for Application in Buried Transuranic Waste Sites, Volume 1, Technology Description and Treatability Study Results for OU 7-13/14. INEEL/EXT-02-00233, Rev. 1, Idaho National Engineering and Environmental Laboratory, Idaho Falls, Idaho.

Moridis GJ, P Persoff, JA Apps, L Myer, K Pruess, and P Yen. 1995. A Field Test of Permeation Grouting in Heterogeneous Soils Using a New Generation of Barrier Liquids. LBL-37554, Lawrence Berkeley National Laboratory, Berkeley, California.

Moridis GJ, P Persoff, P Yen, L Myer, S Finsterle, P Williams, and K Pruess. 1996a. A Design Study for a Medium-Scale Field Demonstration of the Viscous Barrier Technology. LBNL-38916, Lawrence Berkeley National Laboratory, Berkeley, California.

Moridis GJ, L Myer, P Persoff, S Finsterle, JA Apps, D Vasco, S Muller, P Williams, P Yen, and K Pruess. 1996b. A Field Test of a Waste Containment Technology Using a New Generation of Injectable Barrier Liquids. LBNL-38817, Lawrence Berkeley National Laboratory, Berkeley, California. 
Moridis GJ, S Finsterle, and J Heiser. 1999. "Evaluation of Alternative Designs for an Injectable Subsurface Barrier at the Brookhaven National Laboratory Site, Long Island, New York." Water Resources Research 35:2937-2953.

ORNL. 1997. Field Grouting Summary Report on the WAG 4 Seeps 4 and 6 Removal Action Project. ORNL/ER-401/V1, Vol. 1 and 2, Oak Ridge National Laboratory, Oak Ridge, Tennessee.

Ozgurel HG and C Vipulanandan. 2005. "Effect of Grain Size and Distribution on Permeability and Mechanical Behavior of Acrylamide Grouted Sand." Journal of Geotechnical and Geoenvironmental Engineering 131(12):1457-1465.

Persoff P, S Finsterle, GJ Moridis, J Apps, K Pruess, and S Muller. 1994. "Injectable Barriers for Waste Isolation." In 33rd Hanford Symposium on Health and Environment, In-Situ Remediation: Scientific Basis for Current and Future Technologies, Part 1, eds. GW Gee and NR Wing, pp. 87-101, Battelle, Columbus, Ohio.

Persoff P, S Finsterle, GJ Moridis, J Apps, K Pruess, and SJ Muller. 1995. Injectable Barriers for Waste Isolation. LBL-36739, Lawrence Berkeley National Laboratory, Berkeley, California.

Persoff P, GJ Moridis, JA Apps, and K Pruess. 1998. "Evaluation Tests for Colloidal Silica for Use in Grouting Applications.” ASTM Geotech. Test. J., 21(3):264-269.

Persoff P, GJ Moridis, JA Apps, and JM Whang. 1999. "Effect of Dilution and Contaminants on Sand Grouted with Colloidal Silica Gel." Journal of Geotechnical Geoenvironmental Engineering 125(6): 461-469.

Serne RJ, GV Last, HT Schaef, DC Lanigan, CW Lindenmeier, CC Ainsworth, RE Clayton, VL Legore, MJ O'Hara, CF Brown, RD Orr, IV Kutnyakov, TC Wilson, KB Wagnon, BA Williams, and DS Burke. 2002. Characterization of Vadose Zone Sediment: Slant Borehole SX-108 in the S-SX Waste Management Area. PNNL-13757-4, Pacific Northwest National Laboratory, Richland, Washington.

Serne RJ, GV Last, GW Gee, HT Schaef, DC Lanigan, CW Lindenmeier, MJ Lindberg, RE Clayton, VL Legore, RD Orr, IV Kutnyakov, SR Baum, KN Geiszler, CF Brown, MM Valenta, and TS Vickerman. 2008a. Characterization of Vadose Zone Sediment: Borehole 299-E33-45 Near BX-102 in the B-BX-BY Waste Management Area. PNNL-14083, Rev. 1, Pacific Northwest National Laboratory, Richland, Washington.

Serne RJ, BN Bjornstad, DC Lanigan, GW Gee, CW Lindenmeier, RE Clayton, VL Legore, MJ O'Hara, CF Brown, GV Last, IV Kutnyakov, DS Burke, TC Wilson, and BA Williams. 2008b. Characterization of Vadose Zone Sediment: Borehole 299-W23-19 [SX-115] in the S-SX Waste Management Area. PNNL-13757-2, Rev. 1, Pacific Northwest National Laboratory, Richland, Washington.

Serne RJ, AL Ward, W Um, BN Bjornstad, DF Rucker, DC Lanigan, and MW Benecke. 2009. Electrical Resistivity Correlation to Vadose Zone Sediment and Pore-Water Composition for the BC Cribs and Trenches Area. PNNL-17821, Pacific Northwest National Laboratory, Richland, Washington. 
Spalding BP and TA Fontaine. 1992. "Field Demonstration of In Situ Grouting of Radioactive Solid Waste Burial Trenches with Polyacrylamide.” ASTM STP 1123, Vol. 2, eds. T.M Gilliam and CC Wiles, American Society of Testing Materials, Philadelphia.

U.S. Army Corps of Engineers. 1995. Chemical Grouting. Engineer Manual 1110-1-3500, Washington, D.C.

Valenta MM, JR Moreno, MB Martin, RE Fern, DG Horton, and SP Reidel. 2000. Particle Size Distribution Data from Existing Boreholes at the Immobilized Low-Activity Waste Site. PNNL-13328, Pacific Northwest National Laboratory, Richland, Washington.

Vipulanandan C and HG Ozgurel. 2009. "Simplified Relationships for Particle-Size Distribution and Permeation Groutability Limits for Soils." Journal of Geotechnical and Geoenvironmental Engineering 135(9): 1190-1197. 


\section{Appendix}

\section{Derivation of Equations to Estimate Grout Penetration}




\section{Appendix}

\section{Derivation of Equations to Estimate Grout Penetration}

See discussion in Section 3.3.2 and Table 3.1 for units on the variables used in the following equations.

\section{A.1 Cylindrical Grout Penetration Derivation}

Darcy's Law using radial distance rather than length is shown in Equation A.1.

$$
Q=\frac{k \rho g A}{\mu}\left[\frac{\left(P_{o}-P\right)}{\left(R-R_{o}\right)}\right]
$$

where $\quad \mathrm{k}=$ sediment permeability

$\mathrm{p}=$ fluid density

$\mathrm{g}=$ gravitational acceleration

$\mu=$ fluid viscosity

$\mathrm{A}=$ cross sectional area

$\mathrm{P}_{\mathrm{o}}=$ pressure at the injection point

$\mathrm{P}=$ pressure at the limit of grout penetration

$\mathrm{R}=$ radius of grout penetration

$\mathrm{R}_{\mathrm{o}}=$ injection device radius.

For a cylindrically-shaped grout injection where $\mathrm{h}$ is the height, the surface area, not including the top or bottom, is shown in Equation A.2.

$$
A=2 \pi h R
$$

For injection, rearranging the equation for volume of a cylinder, $\mathrm{V}=\pi \mathrm{h} \mathrm{R}^{2}$, accounting for sediment porosity, $\mathrm{n}$, and using $\mathrm{Q}=\mathrm{V} / \mathrm{t}$, where $\mathrm{t}$ is the injection time leads to Equation A.3.

$$
R=\left(\frac{Q t}{n h \pi}\right)^{1 / 2}
$$

For a setting gel, viscosity is a function of time and can be represented as Equation A.4 as described in the report text (see Section 3.3.2).

$$
\mu_{g e l}=a_{1}+a_{2} e^{a_{3} t}
$$


Combining and rearranging these equations gives Equation A.5 to predict the pressure response during injection.

$$
P_{o}=P+Q\left[\frac{\left(\frac{Q t}{n h \pi}\right)^{1 / 2}-R_{o}}{2 \pi h\left[\frac{k \rho g}{\left(a_{1}+a_{2} e^{\left(a_{3} t\right)}\right)}\right]\left[\frac{Q t}{n h \pi}\right]^{1 / 2}}\right]
$$

\section{A.2 Spherical Grout Penetration Derivation}

Darcy's Law using radial distance rather than length is shown above in Equation A.1.

For a spherically shaped grout injection, the surface area is shown in Equation A.6.

$$
A=4 \pi R^{2}
$$

For injection, rearranging the equation for volume of a sphere, $V=(4 / 3) \pi R^{3}$, accounting for sediment porosity, $\mathrm{n}$, and using $\mathrm{Q}=\mathrm{V} / \mathrm{t}$ leads to Equation A.7.

$$
R=\left(\frac{0.75 Q t}{n \pi}\right)^{1 / 3}
$$

For a setting gel, viscosity is a function of time and can be represented as Equation A.4 as described in the report text.

Combining these equations and rearranging gives Equation A.8 to predict the pressure response during injection.

$$
P_{o}=P+Q\left[\frac{\left(\frac{0.75 Q t}{n \pi}\right)^{1 / 3}-R_{o}}{4 \pi\left[\frac{k \rho g}{\left(a_{1}+a_{2} e^{\left(a_{3} t\right)}\right)}\right]\left[\left[\frac{0.75 Q t}{n \pi}\right]^{1 / 3}\right]^{2}}\right]
$$




\section{Distribution}

No. of

Copies

ONSITE

2 DOE Richland Operations Office

RD Hildebrand

A6-38

JG Morse

2 CH2M HILL Plateau Remediation Company

MW Benecke

GB Chronister

R3-60

R3-60
No. of

Copies

5 Pacific Northwest National Laboratory

MJ Nimmons

K6-96

SV Mattigod

EM Pierce

MJ Truex (2)
K3-62

ORNL

K6-96

Distr.1 



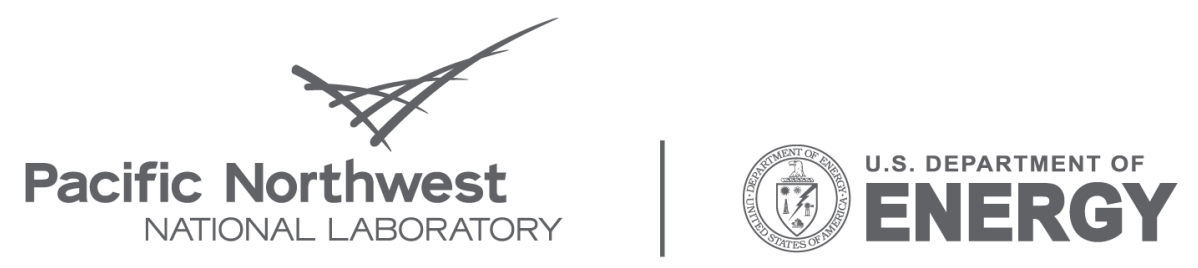

Proudly Operated by Battelle Since 1965

902 Battelle Boulevard

P.O. Box 999

Richland, WA 99352

1-888-375-PNNL (7665)

www.pnl.gov 